\title{
Zunanja pričakovanja potencialnih pridobiteljev nepremičninskih pravic v Sloveniji in na Japonskem
}

V članku so prikazani delni rezultati raziskave, ki poteka v Sloveniji in na Japonskem in katere temeljni cilj je določitev dejavnikov, ki odločilno vplivajo na potencialne pridobitelje nepremičninskih pravic pri odločanju za nakup nepremičnine. $\mathrm{V}$ članku razpravljamo o vlogi zunanjih pričakovanj potencialnih pridobiteljev nepremičninskih pravic glede na njihovo različno kulturno pripadnost. Sledimo hipotezi, da so statistično pomembne razlike v zunanjih pričakovanjih potencialnih pridobiteljev nepremičninskih pravic glede na njihovo različno kulturno pripadnost. Osrednji pripomoček za merjenje pričakovanj udeležencev je vprašalnik, na katerega je odgovorilo 1.270 udeležencev. Rezultate smo statistično analizirali z uporabo enosmerne analize variance glede na različno kulturno pripadnost udeležencev. $Z$ analizo rezultatov statističnih analiz smo potrdili hipotezo. Iz rezultatov je razvidno, da imajo slovenski udeleženci manjša pričakovanja glede zakonskih, davčnih in drugih regulativnih ukrepov države na stanovanjskem področju kot japonski udeleženci. $\mathrm{Ob}$ upoštevanju, da je glavni vzvod države na trgu nepremičnin prav zakonodaja, pričakovanja udeležencev naše raziskave kažejo, da bi bilo treba v Sloveniji prav na tem področju vzpostaviti večje zaupanje potrošnikov.

Ključne besede: pričakovanja kupcev, nepremičninske pravice, Slovenija, Japonska 


\section{Uvod}

Pričakovanja potencialnih kupcev nepremičnin glede pridobitve nepremičninskih pravic so različna in se ločijo glede na potrebe kupcev, njihove želje in interese, pravno dopustne možnosti ter materialne zmožnosti v sodobnih ekonomskih okoljih. Številni raziskovalci na podlagi svojih opazovanj udeležencev na trgu pripisujejo nekaterim dejavnikom splošen vpliv na trg (Cohen idr., 2005; Temeljotov Salaj, 2005; Sendi, 2005; Thomas, 2008). Joe Wong in Eddie Hiu (2006) te dejavnike združujeta v dejavnike lastnih pričakovanj in dejavnike zunanjih pričakovanj. Lastna pričakovanja povezujeta s potencialnimi pridobitelji nepremičninskih pravic, $\mathrm{z}$ investitorji in lastniki, ki pričakujejo visoke (nizke) donose v prihodnosti, ko trg raste (pada), in imajo prevelika (premajhna) pričakovanja glede dvigovanja (padanja) cen v pričakovanju nadaljnje rasti (padanja) cen na trgu. Zunanja pričakovanja udeležencev povezujeta s spreminjanjem cen na trgu in $\mathrm{z}$ regulativnimi ukrepi države. Ugotavljata, da država predvsem v času pričakovanja rasti cen spodbuja investicije in lastništvo prek regulativnih ukrepov, banke pa nudijo ugodne kredite. Dejavniki zunanjih pričakovanj tako združujejo predvsem dejavnike, ki opisujejo stanovanjsko in davčno zakonodajo, regulativne ukrepe in ekonomsko stanje na trgu stanovanjskih nepremičnin.

$\mathrm{V}$ analizi nas zanimajo zunanja pričakovanja potencialnih pridobiteljev nepremičninskih pravic $\mathrm{v}$ različnih kulturnih okoljih. Zanima nas, ali udeleženci glede na svojo pripadnost različnim kulturam izražajo statistično pomembne razlike glede zunanjih pričakovanj. Pod zunanja pričakovanja uvrščamo pričakovanja udeležencev glede vodenja stanovanjske politike države, davčnih ukrepov države, regulativnih ukrepov države, povečanja ponudbe nepremičnin in gibanja cen na nepremičninskem trgu, sprememb ekonomskega položaja, finančnega položaja potencialnih kupcev, stopnje brezposelnosti v državi in primernosti trenutka za nakup nepremičnine (Grum, v tisku). Zanimajo nas pričakovanja udeležencev v dveh različnih kulturnih okoljih, v Sloveniji kot delu EU in na Japonskem, visoko razviti azijski državi. Selekciiski kriterij za izbor teh dveh kulturnih okolij je visok odstotek lastniško zasedenih stanovanj. Po podatkih Eurostata (internet 1) je v Sloveniji v letu 2007 imelo svoje domovanje v lasti 80 \% gospodinjstev. Po podatkih japonskega ministrstva za okolje, infrastrukturo, transport in turizem (2009) je v istem obdobju na Japonskem imelo svoje domovanje v lasti $60 \%$ gospodinjstev.

V opisani raziskavi poskušamo povečati razumevanje vloge, ki jo ima različno kulturno okolje na pričakovanja potencialnih pridobiteljev nepremičninskih pravic. Izhajamo iz hipoteze, da so statistično pomembne razlike $\mathrm{v}$ pričakovanjih potencialnih pridobiteljev nepremičninskih pravic, in sicer glede na različno kulturno pripadnost (Slovenija, Japonska), na področju stanovanjske politike, davčnih ukrepov, regulativnih ukrepov, povečanja ponudbe nepremičnin in gibanja cen na nepremičninskem trgu, spremembe ekonomskega položaja $\mathrm{v}$ državi in lastnega finančnega položaja, stopnje brezposelnosti v državi in primernosti trenutka za nakup nepremičnine. $\mathrm{V}$ prispevku so najprej obravnavana zunanja pričakovanja, nato pa sledijo predstavitev metodologije in pripomočkov ter rezultati oziroma ugotovitve raziskave, na koncu pa še sklep.

\section{Zunanja pričakovanja potencialnih pridobiteljev nepremičninskih pravic}

Zanimajo nas pričakovanja potencialnih pridobiteljev nepremičninskih pravic glede na stanovanjsko politiko $\mathrm{v}$ državi. Zunanja pričakovanja najbolj izražajo stanovanjsko politiko v državi. Pri tem stanovanjsko politiko države razumemo kot vsakokratno nacionalno usmerjeno politiko, $s$ katero država in njeni akterji, upoštevaje družbene in druge elemente oblikovanja javne politike, zlasti elemente nepremičninskega trga in socialnih potreb, ustvarjajo možnosti za enotno in transparentno vodenje stanovanjskega področja (Štritof Brus, 2009). Stanovanjska politika je torej povezana tudi z dostopnostjo stanovanj (kot so dovolj veliko število stanovanj na trgu, ki ustreza povpraševanju, ujemanju povpraševanja in ponudbe, cenovna dostopnost stanovanj in tudi primernost stanovanjskih stroškov) (Cirman, 2007). Dosegljivost stanovanj, merjena po mednarodno uveljavljeni meji, po kateri stanovanjski stroški naj ne bi presegali 30-odstotne meje razpoložljivega dohodka $\mathrm{v}$ gospodinjstvu, je v obeh primerjanih državah različna. Po podatkih, ki jih je objavil Statistični urad Republike Slovenije (2009), je v Sloveniji seštevek stanovanjskih stroškov presegel 30 \% razpoložljivega dohodka gospodinjstva že v letu 2005 s 30,8 \%, v letu 2006 z 31,3 \% in v letu 2007 z 31,8 \%. Po podatkih japonskega statističnega urada (2007) je to razmerje na Japonskem bistveno ugodnejše, in sicer se giblje od 17,6 \% v letu 2001 do slabih $18 \%$ v letu 2008. Kot navaja Andreja Cirman (2007), pa dosegljivost stanovanj ni problematična le pri obremenitvi dohodka s stanovanjskimi stroški, temveč tudi pri pridobitvi stanovanj oziroma dosegljivosti stanovanj z vidika financiranja lastniškega stanovanja. Gospodinjstva se pri tem srečujejo z izrazito nezadostno ponudbo neprofitnega sektorja, dragimi tržnimi stanovanji in visokimi cenami lastniških stanovanj. Za slovensko stanovanjsko politiko je torej značilna relativno slaba dosegljivost lastniških stanovanj, kar pomeni, da slovenska politika v zagotavljanju ustreznih cenovno dosegljivih stanovanj ni preveč uspešna (Cirman, 2007). Težave lahko pripisujemo tudi nerešeni problematiki denacionalizacije, oteženi prodaji nepremičnin tujcem, težavam z vpisi v zemljiško knjigo in njeno ažurnostjo, kar vpliva tudi na posojilno politiko države (Temeljotov Salaj in Zupančič, 2006). 
Zanimajo nas pričakovanja potencialnih pridobiteljev nepremičninskih pravic glede na davčne ukrepe v državi. Ekonomisti še niso našli enotnega odgovora na vprašanje vpliva davka na nepremičnine in na porazdelitev davčnega bremena. Empirične analize $\mathrm{v}$ zvezi $s$ tem vprašanjem temeljijo predvsem na izkušnjah ZDA in Velike Britanije (Pušnik, 1999). Na davčnem področju je največji problem pri davku na nepremičnine določitev davčne osnove. Država ali lokalna skupnost mora oceniti tržno vrednost vseh nepremičnin, ki so podvržene obdavčenju. V Sloveniji je bila ovira zlasti dejstvo, da nismo imeli množičnega vrednotenja nepremičnin (Macarol, 2009). $S$ sprejetjem Zakona o množičnem vrednotenju nepremičnin (Ur. l. RS, št. 50/2006) je ta ovira odpravljena. Na Japonskem se vsako leto javno objavijo stabilizirane cene standardnih nepremičnin. Objava cen se izvaja skladno z zakonom o javni objavi cen nepremičnin (ang. Public notice of land price law, Japan Official Gazette, št. 49/1969). Podobno funkcijo kot navedeni japonski zakon o javni objavi cen nepremičnin bo v Sloveniji opravljal omenjeni zakon o množičnem vrednotenju nepremičnin. Namen tega zakona je urediti ocenjevanje vrednosti nepremičnin v Republiki Sloveniji na podlagi množičnega vrednotenja nepremičnin zaradi obdavčenja in drugih javnih namenov.

Zanimajo nas pričakovanja udeležencev glede spremembe ponudbe nepremičnin na trgu in gibanja cen nepremičnin na trgu. Problematika glede dosegljivosti stanovanj se kaže tudi v zagotavljanju primerne ponudbe stanovanj (Mandič idr., 2006). Država s svojim ravnanjem pomembno vpliva na trg nepremičnin tako na strani ponudbe in povpraševanja kot tudi v normativnem smislu. Kot navaja Igor Šoltes (2009), je normativni del še pomembnejši, saj je odgovor trga odgovor na zakonski okvir, ki določa omejitve in možnosti pri razpolaganju z nepremičninami. Pomembno je torej, kako država ravna $s$ svojim stvarnim premoženjem, ki je pomemben finančni vir. Po Šoltesu (2009) delovanje trga nepremičnin v državni lasti ne more biti učinkovito in uspešno, dokler ne bodo vzpostavljene natančne evidence in dokler ne bo urejeno stanje vpisov nepremičnin v zemljiški knjigi. Na gospodarsko krizo v letu 2008 se je močno odzval tudi nepremičninski trg v Sloveniji in tudi na Japonskem. V Sloveniji je na nacionalni ravni v letu 2008 število transakcij z zazidljivimi zemljišči v primerjavi z letom 2007 padlo za 18 \% (Geodetska uprava Republike Slovenije, 2009), na Japonskem pa za 10 \% (ministrstvo za okolje, infrastrukturo, transport in turizem, 2009). Cene stanovanj v Tokiu so v letu 2009 v primerjavi s prejšnjim letom padle za 19,4 \% (ministrstvo za okolje, infrastrukturo, transport in turizem, 2009), v Ljubljani pa za 4,8 \% (Geodetska uprava Republike Slovenije, 2009).

Zanima nas, ali v času izrazitega spreminjanja cen stanovanj obstaja razhajanje med ekonomskimi modeli, ki kratkoročno pojasnjujejo vzorce spreminjanja cen, in pričakovanji udeležencev. Jan Rouwendal in Simonetta Longhi (2008) to razliko pripisujeta spremenljivki, ki pri potrošnikih splošno psihološko izraža občutek optimizma ali pesimizma. Tako investitorji in lastniki pričakujejo visoke (nizke) donose, kadar trg raste (pada) oziroma imajo prevelika (premajhna) pričakovanja glede gibanja cen na trgu (Wong in Hiu, 2006). Wong in Hiu (2006) ugotavljata, da so v realnosti investitorji ali lastniki dovzetnejši za obnašanja drugih investitorjev ali lastnikov kot za realne tržne razmere. Ugotavljata, da država v času pričakovanja rasti cen spodbuja investicije in lastništvo prek regulativnih ukrepov, banke pa nudijo ugodne kredite. Visoka pričakovanja glede stanovanj lahko negativno vplivajo na dostopnost stanovanj (Thomas, 2008). Da so vlagatelji na stanovanjskem trgu prepogosto nerealno in preveč optimistični, sta ugotovila tudi Wong in Hiu (2006). Izhajala sta iz Pygmalionove hipoteze, v kateri se predvideva, da gre za prerokbe, ki uresničujejo same sebe - v slovenski literaturi se ta izraz uporablja kot samouresničujoče se prerokbe ali samouresničujoče se napovedi (Kobal, 2001). Samouresničujoče se prerokbe se pojavijo, ko » napačen koncept razumevanja položaja zbudi novo obnašanje, ki naredi izvirno napačen koncept resničen « (Merton, 1957:36). Ljudje se ne obnašajo vedno racionalno. Njihove težnje so bolj optimistične, kadar cene na nepremičninskem trgu rastejo, in bolj pesimistične, kadar cene padajo. Dokler udeleženci pričakujejo rast cen na nepremičninskem trgu, njihovo obnašanje ustvarja višje zahteve. Pričakovanja, da bodo cene naraščale tudi v prihodnje, vodijo $\mathrm{v}$ povečanje dobave oziroma ponudbe na trgu, kar v nasprotju s pričakovanji niža cene nepremičnin, dokler trg ne doseže ravnovesja. To kaže na to, da lahko upanja, želje, pričakovanja in samouresničujoče se prerokbe, naj bodo pravilne ali ne, vplivajo na trg nepremičnin (Wong in Hiu, 2006).

Zanimajo nas pričakovanja glede ekonomskega položaja v državi. Globalna kriza se v obeh državah kaže v spremenjenem gibanju rasti bruto domačega proizvoda (v nadaljevanju: BDP). BDP se je v Sloveniji po letu 2007, ko je realna stopnja rasti dosegla 6,8 \%, zmanjševal do leta 2009, ko je bila zabeležena negativna rast, in sicer $-7,8 \%$ (Urad za makroekonomske raziskave, 2010). Iz napovedi lahko vidimo, da se pričakuje rahlo povečanje BDP v letu 2010, in sicer na $0,9 \%$, v letu 2011 pa na 2,5\%. Po navedbah japonskega nepremičninskega inštituta (2009) se je v letu 2008 rast BDP tudi na Japonskem po dolgi dobi okrevanja (pozitivne rasti) znižala. Po napovedi istega vira je bila negativna rast zabeležena $v$ letu 2009, pozitivna rast pa je napovedana za leti 2010 in 2011, v katerih naj bi odstotek rasti znašal blizu $2 \%$.

Zanimajo nas pričakovanja glede stopnje brezposelnosti v državi. Svetovna gospodarska kriza je bistveno spremenila gibanja cen na trgu nepremičnin v večini držav, tudi v Sloveniji in na Japonskem. Kot navaja Alenka Kajzer (2009), se je finančna 
kriza, ki je izbruhnila v letu 2007, postopoma prenesla v realni sektor in se spremenila v gospodarsko krizo. Za Slovenijo je bila v letu 2007 značilna izjemno visoka gospodarska rast, ki se je v letu 2008 upočasnila, proti konca leta 2008 pa je že bil zabeležen padec gospodarske dejavnosti, merjene z rastjo bruto domačega proizvoda. Podobna gibanja je bilo mogoče zaznati tudi na Japonskem, kjer se je v letu 2008 končalo nekajletno okrevanje gospodarstva po veliki recesiji, ki jo je Japonska doživela v letu 1991. Neugodna gospodarska gibanja v letu 2008 so spremenila gospodarske dejavnosti v obeh državah. Po mnenju Alenke Kajzer (2009) je to vplivalo na trg dela, v primerjavi z letom 2007 pa so bile zaznane tudi bistvene spremembe pri gibanju plač. Zaradi naraščanja brezposelnosti se je država Slovenija odzvala tako, da je okrepila izvajanje programov aktivne politike zaposlovanja. Sprejeta sta bila intervencijska zakona, namenjena ohranjanju delovnih mest. Januarja 2009 je bil sprejet Zakon o delnem subvencioniranju polnega delovnega časa (Ur. l. RS, št. 5/2009), konec maja pa Zakon o delnem povračilu nadomestila plače (Ur. l. RS, št. 42/2009). Japonska vlada se je s krizo spoprijela tako, da je v letu 2009 sprejela stimulativen ukrep, vreden 173 milijard USD, kar je več, kot je znašala skupna vrednost vseh ukrepov v letu 2008 (globalni nepremičninski vodnik, 2009). Vse navedeno je vplivalo na gibanja realne stopnje rasti BDP. V obeh državah je bil zaznan močan padec BDP v letih 2008 in 2009 ter povečanje $\mathrm{v}$ letu 2010 kot posledica sprejetih vladnih protikriznih ukrepov. Napovedi za leto 2011 so pozitivne za Slovenijo in Japonsko. V obeh državah je predvidena enakomerna, stalna 2-odstotna rast BDP. Zanimiv je tudi sklep raziskave, ki sta jo izvedla Wong in Hiu (2006). Ugotovila sta, da je kar 95 \% japonskih udeležencev odgovorilo, da so pri odločanju za nakup stanovanja pomembni dejavniki, kot so ekonomsko stanje, obrestna mera in družinski prihodki, skoraj v celoti po so zanemarili vprašanje o stopnji brezposelnosti, ki je bila med opravljanjem navedene ankete zelo visoka.

Zanimajo nas pričakovanja glede pravega trenutka za nakup nepremičnine v naslednjih šestih mesecih. Trg stanovanjskih nepremičnin, ki je ob koncu leta 2008 in v prvi polovici leta 2009 v pričakovanju precejšnjega padca cen skoraj zamrl, je v četrtem četrtletju 2009 pokazal znake okrevanja (Geodetska uprava Republike Slovenije, 2009). Število transakcij se je precej okrepilo (za $70 \%$ glede na predhodno četrtletje) in se približalo povprečju iz obdobja pred krizo. Statistični urad Republike Slovenije (2010) navaja, da še ni jasno, ali pomeni to povečanje že oživitev običajnega trga ali le trenutno uresničitev tistih nujnih nepremičninskih transakcij, ki so bile v preteklem letu zaradi pričakovanega znižanja cen zadržane ali prestavljene. Čeprav v Sloveniji kazalnik gospodarskega duhovnega ozračja in tudi kazalnik zaupanja $\mathrm{v}$ gradbeništvo kažeta umerjanje, pa po napovedi istega vira ni rečeno, da bodo izražena pričakovanja udeležencev temu sledila. Tudi za Japonsko je značilno, da se zaupanje kupcev v nepremičninski trg počasi vrača, zato se pričakuje okrevanje stanovanjskega nepremičninskega trga (globalni nepremičninski vodnik, 2009). Po poročanju japonskega inštituta za ekonomske in socialne raziskave (inštitut za ekonomske in socialne raziskave, 2010) indeks zaupanja potrošnikov, ki je v letih 2006, 2007 in 2008 konstantno padal, ponovno raste.

\section{Metodologija in pripomočki}

Osrednji pripomoček za merjenje pričakovanj udeležencev je vprašalnik, ki smo ga sestavili sami. Sestava vprašalnika je del širše raziskave, ki poteka v dveh kulturnih okoljih, v Sloveniji in na Japonskem, in katere temeljni cilj je določiti dejavnike, ki so za potencialne kupce nepremičnin odločilni pri odločanju za nakup nepremičnine, razčleniti morebitne razlike med navedenimi pričakovanji in obstoječo zakonodajo na področju nepremičnin in ugotoviti, ali se sodobno ekonomsko okolje pozitivno povezuje z navedenimi pričakovanji (Grum, v tisku). Pri zgradbi vprašalnika smo upoštevali usmeritev po Tariku M. Al-Solimanu (1990) in vzeli za osrednji pripomoček za merjenje pričakovanj udeležencev vprašalnik, sestavljen iz treh sklopov. Prvi sklop meri demografske dejavnike, drugi sklop meri lastna pričakovanja udeležencev, tretji skop pa meri zunanja pričakovanja udeležencev. Uporabljena je metoda pregleda, ki temelji na vprašalniku (Walonic, 2007). Udeleženci so na vprašanja odgovarjali s pomočjo Likertove lestvice, pri čemer je vrednost 5 pomenila, da se $s$ trditvijo popolnoma strinjajo, vrednost $1 \mathrm{pa}$, da se s trditvijo sploh ne strinjajo. Zbiranje podatkov je potekalo prek osebne korespondence in prek interneta. Anonimnost sodelujočih v anketi je bila zagotovljena. Podatki so bili obdelani s statističnim programom SPSS.

Pri analizi zunanjih pričakovanj smo uporabili prvi in tretji sklop vprašalnika, ki smo ju predhodno faktorizirali. Prvi sklop vprašalnika meri demografske dejavnike in zajema 34 spremenljivk. Ekstrahirali smo osem dejavnikov, ki pojasnijo nad $60 \%$ variacije (Bastič, 2006). Kaiser-Meyer-Olkinova mera adekvatnosti vzorčenja je 0,7. Barlettov test $(\mathrm{BT}=2178,1)$, ki je statistično pomemben, kaže, da je ekstrahirane dejavnike mogoče interpretirati (Fulgosi, 1984). Rezultati tretjega sklopa vprašalnika, vezanega na zunanja pričakovanja, kažejo, da štirje dejavniki pojasnijo nad 61 \% variance. Kaiser-Meyer-Olkinova mera adekvatnosti vzorčenja je 0,9. Barlettov test (BT = 2791,8), ki je statistično pomemben, kaže, da je ekstrahirane štiri dejavnike mogoče interpretirati. Zanesljivost vprašalni$\mathrm{ka}$, ugotovljena $\mathrm{z}$ metodo notranje konsistentnosti oziroma $\mathrm{s}$ Cronbachovim koeficientom alfa, kaže, da vprašalnik izkazuje veliko stopnjo zanesljivosti. Cronbachov koeficient alfa za prvi sklop vprašalnika znaša 0,8 , za tretji skop pa 0,6. 
Preglednica 1: Struktura udeležencev glede na kulturno pripadnost, spol, starost, izobrazbo, družinski status, število otrok v skupnem gospodinjstvu, kraju bivanja

\begin{tabular}{|c|c|c|c|c|c|c|}
\hline & \multicolumn{2}{|c|}{ Slovenski udeleženci } & \multicolumn{2}{|c|}{ Japonski udeleženci } & \multicolumn{2}{|c|}{ Udeleženci skupaj } \\
\hline & $n$ & $\%$ & $n$ & $\%$ & $n$ & $\%$ \\
\hline \multicolumn{7}{|l|}{ Kulturna pripadnost } \\
\hline udeleženci & 1.006 & 79,2 & 264 & 20,8 & 1.270 & 100,0 \\
\hline \multicolumn{7}{|l|}{ Spol } \\
\hline ženske & 623 & 49,0 & 90 & 7,0 & 713 & 56,1 \\
\hline moški & 383 & 30,1 & 174 & 13,7 & 557 & 43,9 \\
\hline skupaj & 1.006 & 79,2 & 264 & 20,8 & 1.270 & 100,0 \\
\hline \multicolumn{7}{|l|}{ Starost } \\
\hline od 20 do 29 let & 490 & 38,6 & 114 & 8,9 & 604 & 47,6 \\
\hline od 30 do 40 let & 516 & 40,6 & 150 & 11,8 & 666 & 52,4 \\
\hline skupaj & 1.006 & 79,2 & 264 & 20,8 & 1.270 & 100,0 \\
\hline \multicolumn{7}{|l|}{ Izobrazba } \\
\hline manj kot srednja šola & 10 & 0,8 & 0 & 0,0 & 10 & 0,8 \\
\hline srednja šola & 370 & 29,1 & 18 & 1,4 & 388 & 30,6 \\
\hline fakultetna izobrazba & 533 & 41,9 & 96 & 7,5 & 629 & 49,5 \\
\hline magisterij ali več & 93 & 7,3 & 150 & 11,7 & 243 & 19,1 \\
\hline skupaj & 1.006 & 79,2 & 264 & 20,8 & 1.270 & 100,0 \\
\hline \multicolumn{7}{|l|}{ Družinski status } \\
\hline samski & 264 & 21,0 & 168 & 13,4 & 432 & 34,5 \\
\hline v zvezi oz. poročen & 731 & 58,3 & 90 & 7,1 & 821 & 65,5 \\
\hline skupaj & 995 & 79,4 & 258 & 20,5 & 1.253 & 100,0 \\
\hline \multicolumn{7}{|c|}{ Število otrok v gospodinjstvu } \\
\hline brez otrok & 486 & 38,7 & 198 & 15,8 & 684 & 54,6 \\
\hline en otrok & 174 & 13,9 & 12 & 0,9 & 186 & 14,9 \\
\hline dva otroka & 251 & 20,0 & 18 & 1,4 & 269 & 21,5 \\
\hline trije otroci & 68 & 5,4 & 30 & 2,3 & 98 & 7,8 \\
\hline štirje otroci ali več & 15 & 1,2 & 0 & 0,0 & 15 & 1,2 \\
\hline skupaj & 994 & 79,3 & 258 & 20,6 & 1.252 & 100,0 \\
\hline \multicolumn{7}{|l|}{ Kje živite (lokacija) } \\
\hline v središču mesta & 316 & 25,2 & 114 & 9,0 & 430 & 34,3 \\
\hline na obrobju mesta & 321 & 25,6 & 132 & 10,5 & 453 & 36,2 \\
\hline v strnjenem podeželju & 234 & 18,7 & 6 & 0,4 & 240 & 19,2 \\
\hline v razpršenem podeželju & 116 & 9,3 & 0 & 0,0 & 116 & 9,3 \\
\hline drugje & 8 & 0,6 & 6 & 0,4 & 14 & 1,1 \\
\hline skupaj & 995 & 79,4 & 258 & 20,5 & 1.253 & 100,0 \\
\hline
\end{tabular}

Raziskavo smo izvedli v dveh kulturnih okoljih, v Sloveniji in na Japonskem. V vzorec so vključeni udeleženci, stari od 20 do 40 let, ki so selekcionirani po kulturni pripadnosti, spolu, starosti, zaposlitvi, zakonskem oziroma družinskem položaju in ekonomsko socialnem položaju. V raziskavi je sodelovalo 1.006 slovenskih udeležencev in 264 japonskih udeležencev.

Iz preglednice 1 je razvidno, da je japonskih udeležencev glede na skupno število udeležencev le dobrih $20 \%$. Navedeno je posledica težav pri pridobivanju odgovorov japonskih udeležencev, saj na Japonskem distribucija vprašalnika na javnih mestih ni dovoljena (brez odobritve posebne etične komisije). V nasprotju s slovenskimi udeleženci se je pri japonskih udeležencih izkazalo veliko nezaupanje do sodelovanja pri internetnih anketah. Glede na izobrazbo ima največ udeležencev fakultetno izobrazbo (49,5\%), sledi srednja izobrazba (30,6 \%). Glede števila otrok v skupnem gospodinjstvu je največ udeležencev brez otrok $(54,0 \%)$. Največ udeležencev živi na obrobju mesta $(36,2 \%)$ ali v središču mesta $(34,3 \%)$.

Iz preglednice 2 je razvidno, da živi največ udeležencev v lastnem ali solastniškem stanovanju (48,3\%), sledijo udeleženci, 
ki bivajo pri sorodnikih (25,9\%). Največ udeležencev živi v hiši $(57,8 \%)$ ali stanovanjskem bloku (40,8 \% ). Največ udeležencev je zaposlenih (59,6 \%). Udeležencev, ki mesečno porabijo za reševanje trenutnega stanovanjskega problema okoli $30 \%$ mesečnega dohodka ali manj, je skupno 84,5\%. Glede zadovoljstva je največ udeležencev zadovoljnih $s$ trenutnim statusom bivanja (29,9\%).

\section{Rezultati in razprava}

Podatke smo analizirali z enosmerno analizo variance glede na kulturno pripadnost (preglednica 3). Statistično pomembne razlike $(\mathrm{p}<0,01)$ glede pričakovanj potencialnih pridobiteljev nepremičninskih pravic glede pripadnosti različnemu kulturnemu okolju se kažejo pri davčnih ukrepih, stanovanjski politiki, regulativnih ukrepih, povečanju ponudbe nepremičnin na trgu, ekonomskem položaju v prihodnjih mesecih, lastnem finančnem položaju v preteklih mesecih in pravem trenutku za nakup nepremičnine. Statistično pomembne razlike $(\mathrm{p}<0,05)$ glede pričakovanj potencialnih pridobiteljev nepremičninskih pravic glede pripadnosti različnemu kulturnemu okolju se kažejo pri ekonomskem položaju v preteklih mesecih in stopnji brezposelnosti.

Preglednica 2: Struktura udeležencev glede na lastništvo stanovanja, tip stanovanja, zaposlenost, mesečno porabo za reševanje stanovanjskega problema in zadovoljstvo s trenutnim statusom bivanja

\begin{tabular}{|c|c|c|c|c|c|c|}
\hline & \multicolumn{2}{|c|}{ Slovenski udeleženci } & \multicolumn{2}{|c|}{ Japonski udeleženci } & \multicolumn{2}{|c|}{ Udeleženci skupaj } \\
\hline & $n$ & $\%$ & $n$ & $\%$ & $n$ & $\%$ \\
\hline \multicolumn{7}{|l|}{ Lastništvo stanovanja } \\
\hline lastno ali solastniško & 531 & 42,5 & 72 & 5,7 & 603 & 48,3 \\
\hline tržno najemniško & 99 & 7,9 & 96 & 7,6 & 195 & 15,6 \\
\hline neprofitno/socialno & 27 & 2,1 & 24 & 1,9 & 51 & 4,1 \\
\hline pri sorodnikih & 269 & 21,5 & 54 & 4,3 & 323 & 25,9 \\
\hline drugo & 64 & 5,1 & 12 & 0,9 & 76 & 6,1 \\
\hline skupaj & 990 & 79,3 & 258 & 20,6 & 1.248 & 100,0 \\
\hline \multicolumn{7}{|l|}{ Tip stanovanja } \\
\hline stanovanjski blok & 366 & 29,2 & 144 & 11,5 & 510 & 40,8 \\
\hline hiša & 608 & 48,6 & 114 & 9,1 & 722 & 57,8 \\
\hline drugo & 17 & 1,4 & 0 & 0,0 & 17 & 1,4 \\
\hline skupaj & 961 & 76,9 & 258 & 23,0 & 1.249 & 100,0 \\
\hline \multicolumn{7}{|l|}{ Zaposlitev } \\
\hline brezposeln & 30 & 2,4 & 6 & 0,4 & 36 & 2,9 \\
\hline študent & 304 & 24,3 & 126 & 10,0 & 430 & 34,4 \\
\hline zaposlen & 630 & 50,4 & 114 & 9,1 & 744 & 59,6 \\
\hline drugo & 27 & 2,1 & 12 & 0,9 & 39 & 3,1 \\
\hline skupaj & 991 & 79,3 & 258 & 20,6 & 1.249 & 100,0 \\
\hline \multicolumn{7}{|l|}{$\begin{array}{l}\text { Za reševanje stanovanjskega } \\
\text { problema porabite: }\end{array}$} \\
\hline nič & 450 & 36,2 & 60 & 4,8 & 510 & 41,1 \\
\hline manj kot 30 \% svojega mesečnega dohodka & 216 & 17,4 & 150 & 12,0 & 366 & 29,5 \\
\hline okoli 30 \% svojega mesečnega dohodka & 149 & 11,9 & 24 & 1,9 & 173 & 13,9 \\
\hline več kot 30 \% svojega mesečnega dohodka & 129 & 10,3 & 24 & 1,9 & 153 & 12,3 \\
\hline skoraj ves dohodek & 40 & 3,2 & 0 & 0,0 & 40 & 3,2 \\
\hline skupaj & 984 & 79,2 & 258 & 20,7 & 1.242 & 100,0 \\
\hline \multicolumn{7}{|l|}{$\begin{array}{l}\text { Zadovoljstvo s trenutnim statusom } \\
\text { stanovanja }\end{array}$} \\
\hline zelo nezadovoljen & 76 & 6,0 & 30 & 2,4 & 106 & 8,5 \\
\hline nezadovoljen & 105 & 8,4 & 24 & 1,9 & 129 & 10,4 \\
\hline srednje zadovoljen & 220 & 17,7 & 48 & 3,8 & 268 & 21,6 \\
\hline zadovoljen & 281 & 22,6 & 90 & 7,2 & 371 & 29,9 \\
\hline zelo zadovoljen & 300 & 24,1 & 66 & 5,3 & 366 & 29,5 \\
\hline skupaj & 982 & 79,1 & 258 & 20,8 & 1.240 & 100,0 \\
\hline
\end{tabular}


Preglednica 3: Prikaz rezultatov analize variance zunanjih pričakovanj potencialnih pridobiteljev nepremičninskih pravic glede na pripadnost različnemu kulturnemu okolju

\begin{tabular}{lcccccc}
\hline Spremenljivke & & Vsota kvadratov & df & Srednji kvad. & $F$ & $p$ \\
\hline davčni ukrepi & $\neq$ & 87,102 & 1 & 87,102 & 94,067 & 0,000 \\
\hline stanovanjska politika & $\neq$ & 47,796 & 1 & 47,796 & 41,938 & 0,000 \\
\hline regulativni ukrepi & $\neq$ & 37,764 & 1 & 37,764 & 40,59 & 0,000 \\
\hline povečanje ponudbe nepremičnin & $\neq$ & 138,583 & 1 & 138,583 & 148,194 & 0,000 \\
\hline gibanje cen na trgu nepremičnin & $\neq$ & 13,332 & 1 & 13,332 & 17,786 & 0,000 \\
\hline ekon. pol. v preteklih mesecih & $*$ & 2,92 & 1 & 2,92 & 5,243 & 0,022 \\
\hline ekon. pol. v prihodnjih mesecih & $\neq$ & 11,753 & 1 & 11,753 & 19,857 & 0,000 \\
\hline fin. pol. v preteklih mesecih & $\neq$ & 20,973 & 1 & 20,973 & 27,809 & 0,000 \\
\hline fin. pol. v prihodnjih mesecih & & 0,447 & 1 & 0,447 & 0,582 & 0,446 \\
\hline brezposelnost & $*$ & 3,382 & 1 & 3,382 & 4,032 & 0,045 \\
\hline pravi trenutek za nakup & $\neq$ & 46,243 & 1 & 46,243 & 45,365 & 0,000 \\
\hline
\end{tabular}

Opombe: * razlika je statistično pomembna $(p<0,05) ; \dagger$ razlika je statistično pomembna $(p<0,01)$; razlika je statistično pomembna $(p<0,001)$

Kot je razvidno s slike 1, imajo slovenski udeleženci večja pričakovanja glede povečanja ponudbe nepremičnin na trgu, ekonomskega položaja v preteklih mesecih in pravega trenutka za nakup nepremičnine. Japonski udeleženci imajo večja pričakovanja glede davčnih ukrepov, stanovanjske politike, regulativnih ukrepov, gibanja cen nepremičnin v prihodnjih mesecih, ekonomskega položaja v prihodnjih mesecih in brezposelnosti.

Glede pričakovanih davčnih ukrepov države se glede na kulturno pripadnost udeležencev kažejo statistično pomembne razlike. Čeprav udeleženci obeh kultur izkazujejo relativno majhna pričakovanja glede davčnih ukrepov države, pa japonski udeleženci izkazujejo večja pričakovanja (povprečna stopnja strinjanja = 2,54). Kot so poudarili že Adistair Adair idr. (2006), spadajo med najpomembnejše dejavnike pri razvoju trga zemljišč in nepremičnin časovno ustrezni in kakovostni tržni podatki ter možnost njihove pravilne predstavitve oziroma razlage. Davek na nepremičnine je eden izmed najstarejših javnih prihodkov. Ta davek je povsod nepriljubljen in velikokrat kritiziran, saj je opaznejši in različen od ostalih davkov, kot sta primer davek na dohodek in davek na dodano vrednost (Bevc, 1997). Največji problem pri tem davku je davčna osnova.

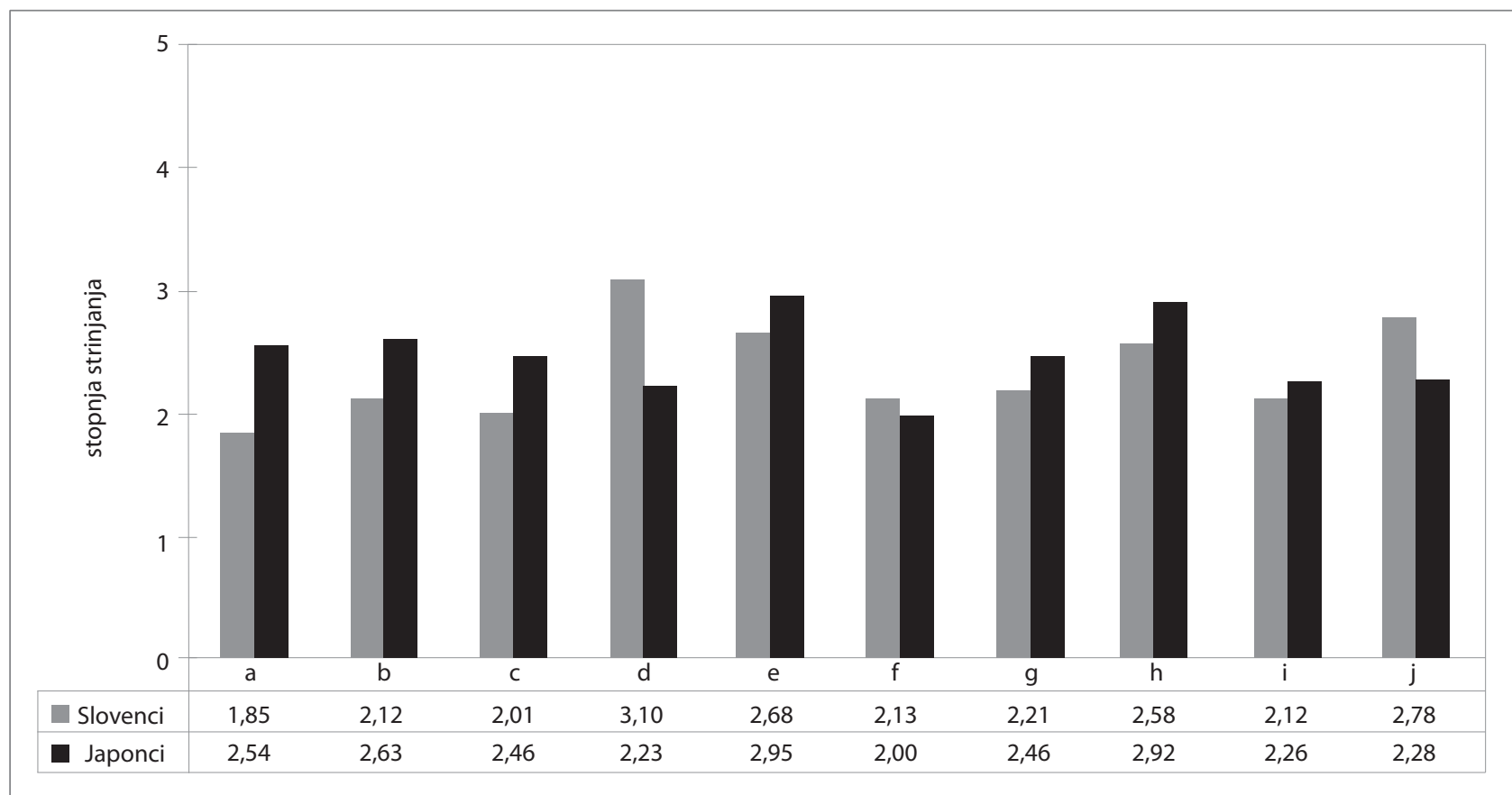

Opomba: (a) davčni ukrepi, (b) stanovanjska politika, (c) regulativni ukrepi, (d) povečanje ponudbe na nepremičninskem trgu, (e) gibanje cen na nepremičninskem trgu, (f) ekonomski položaj v državi v preteklih šestih mesecih, (g) ekonomski položaj v državi v prihodnjih šestih mesecih, (h) lasten finančni položaj v preteklih šestih mesecih, (i) stopnja brezposelnosti, (j) pravi trenutek za nakup nepremičnine.

Slika 1: Povprečna stopnja strinjanja za prepoznanje statistično pomembnih razlik med slovenskimi in japonskimi udeleženci 
V Sloveniji je bila s sprejetjem Zakona o množičnem vrednotenju nepremičnin (Ur. l. RS, 50/2006) odpravljena ovira pri izvajanju Zakona o davkih občanov (Ur. l. RS, št. 36/1988). Na podlagi navedenih zakonov se v Sloveniji vzpostavlja davek na nepremičnine, ki pa po Šoltesu (2009) ne more učinkovito in uspešno delovati, dokler niso vzpostavljene natančne evidence in dokler ni urejeno stanje vpisov nepremičnin $\mathrm{v}$ zemljiški knjigi. Na Japonskem je bil že leta 1991 sprejet zakon o davku na posest zemlje (ang. Landholding tax, Japan Official Gazette, št. 69/1991), katerega namen je bilo predvsem preprečiti špekulacije z zemljišči, katerih cene so pred letom 1990 hitro naraščale. Osnovni zakon o zemljiščih (ang. Basic act for land, Japan Official Gazette, št. 84/1989) je odgovor na japonsko grenko izkušnjo, pri kateri so med visoko gospodarsko rastjo cene zemljišč izjemno rasle, kar je spodbujalo špekulativne transakcije (Yoshida, 2002). Skladno z zakonom o javni objavi cen nepremičnin (ang. Public notice of land price law, Japan Official Gazette, šst. 49/1969) se vsako leto javno objavijo normalne cene standardih nepremičnin. Namen javnega obvestila je zagotoviti smernice splošnih transakcijskih cen, poleg navedenega pa so objavljene cene uporabljene kot smernice za oceno davka na dediščino in davka od vrednosti osnovnih sredstev.

Pričakovanja glede spodbujevalne stanovanjske politike države v prihodnjih letih glede na kulturno pripadnost udeležencev kažejo statistično pomembne razlike. Čeprav udeleženci obeh kultur izkazujejo relativno majhna pričakovanja, imajo japonski udeleženci večja pričakovanja (povprečna stopnja strinjanja $=2,63$ ). Andreja Cirman (2007) ugotavlja, da je za Slovenijo v splošnem značilna relativno slaba doseglijivost lastniških stanovanj. Če se vprašamo, ali je glavni vzvod države na trgu nepremičnin prav zakonodaja, Mojca Štritof Brus (2009) navaja, da lahko odgovorimo pritrdilno. Med bolj pozitivne vplive po njenem mnenju spada dejstvo, da dostop do podatkov evidence trga nepremičnin omogoča iskanje, pregledovanje in izvoz vseh posredovanih podatkov o sklenjenih kupoprodajnih in najemnih pravnih poslih (razen osebnih podatkov pogodbenih strank), ki je vsekakor v pomoč pri oblikovanju cen, oglaševanju in trženju.

Glede pričakovanih regulativnih ukrepov države v prihodnjih letih izkazujejo japonski udeleženci večja pričakovanja (povprečna stopnja strinjanja $=2,46$ ). Navedeno lahko pojasnimo $s$ prizadevanji japonske vlade, ki je uvedla več sprememb, da bi pomagala oživiti gospodarstvo in omiliti težave, $s$ katerimi se srečujejo kreditojemalci stanovanjskih kreditov. Kot navajajo Ray Forrest idr. (2003), so ti ukrepi vključevali zmanjšanje standardne obrestne mere in povečanje najvišjega zneska posojil za nove nakupe ali obnovo doma, sočasno pa je bil za najbolj ogroženo skupino podaljšnn rok za odplačevanje kreditov $s$ treh na deset let. Obe državi sta se odzvali na poslabšanje stanja na trgu dela z ukrepi politike dela in $s$ subvencijami. Neugodna gospodarska gibanja v letu 2008 so spremenila gospodarske dejavnosti v obeh državah. To je vplivalo na trg dela, zaznane pa so bile tudi bistvene spremembe pri gibanju plač v primerjavi z letom 2007 (Kajzer, 2009). Na naraščanje brezposelnosti se je država Slovenija odzvala tako, da je okrepila izvajanje programov aktivne politike zaposlovanja (prav tam). Japonska vlada se je s krizo spoprijela tako, da je v letu 2009 sprejela stimulativen ukrep, vreden 173 milijard USD, kar je več, kot je znašala skupna vrednost vseh ukrepov v letu 2008 (globalni nepremičninski vodnik, 2009). Glede na to, da imajo slovenski udeleženci manjša pričakovanja glede pričakovanih regulativnih ukrepov države $\mathrm{v}$ naslednjih petih letih, lahko sklepamo, da slovenska država $s$ sprejemanjem zakonov na področju nepremičnin ne dosega učinkov, ki bi vodili v večje zaupanje potencialnih kupcev nepremičnin.

Slovenski udeleženci imajo bistveno večja pričakovanja glede povečanja ponudbe nepremičnin na trgu (povprečna stopnja strinjanja $=3,10$ ), japonski udeleženci pa imajo večja pričakovanja glede dviga cen nepremičnin (povprečna stopnja strinjanja $=2,68)$. Število transakcij z zazidljivimi zemljišči v letu 2008 je v primerjavi z letom 2007 na nacionalni ravni v Sloveniji padlo za $18 \%$ (Geodetska uprava Republike Slovenije, 2009), na Japonskem pa za 10 \% (ministrstvo za okolje, infrastrukturo, transport in turizem, 2009). Slovenski udeleženci imajo torej v splošnem večja pričakovanja glede povečanja ponudbe, kar je lahko posledica pojava presežka stanovanj na trgu. $\mathrm{Na}$ Japonskem so cene nepremičnin padale od zloma nepremičninskega trga leta 1990. Japonski nepremičninski trg je okrevanje cen doživel šele pred nekaj leti. Gibanje cen nepremičnin od leta 1991 do leta 2008 je torej v obeh državah zelo različno. Za Slovenijo je bila v tem obdobju značilna izrazita rast cen nepremičnin, ki je vrhunec intenzivnosti dosegla leta 2006 (Geodetska uprava Republike Slovenije, 2009). Cene zazidljivih zemljišč v Sloveniji so v tem odboju v povprečju zrastle za več kot petkrat. Za Japonsko je značilno obratno gibanje cen. Po zlomu nepremičninska trga $\mathrm{v}$ letu 1991 so cene strmo padale in se stabilizirale šele v letu 2006, ko je trg začel okrevati (ministrstvo za okolje, infrastrukturo, transport in turizem, 2009). Glede na navedeno lahko sklepamo, da japonski udeleženci s tem, ko imajo večja pričakovanja glede rasti cen nepremičnin, izražajo prepričanje, da je krivulja padanja cen, ki se je obrnila v pozitivno smer šele leta 2006, že dosegla dno. To lahko pojasnimo tudi z rezultati javnih anket, ki jih spremlja japonski inštitut za ekonomske in socialne raziskave (2010). V začetku leta 2010 so anketiranci izrazili naslednje: $31,2 \%$ jih je menilo, da bodo cene ostale na isti ravni; $24,5 \%$ jih je menilo, da bodo cene nepremičnin padle; $28,8 \%$ jih je menilo, da bodo cene zrastle, in $15,5 \%$ anketirancev se ni opredelilo. V začetku leta 2009 pa so anketiranci izrazili naslednje: $24 \%$ jih je menilo, da bodo cene ostale na isti ravni; $15 \%$ jih je menilo, da bodo cene nepremičnin padle; $44,7 \%$ jih je menilo, da bodo cene zrastle, in 16,3\% anketirancev se ni opredelilo. Glede na navedeno lahko ugotovimo, da se pri 
Japoncih pričakovanja glede gibanja cen sicer zmanjšujejo, še vedno pa nakazujejo pozitiven trend, kar ugotavljamo tudi s svojo raziskavo. Na navedeno se navezuje tudi izražena razlika pri pričakovanjih udeležencev glede spremembe ekonomskega položaja v državi v preteklih in prihodnjih mesecih. Slovenski udeleženci glede na japonske menijo, da je bil ekonomski položaj v državi v preteklih šestih mesecih bolǰsi (povprečna stopnja strinjanja $=2,13$ ), medtem ko imajo japonski udeleženci večja pričakovanja glede položaja v državi v prihodnjih mesecih (povprečna stopnja strinjanja $=2,46$ ). Zanimivo pa je, da japonski udeleženci glede na slovenske menijo, da je bil njihov finančni položaj v preteklih mesecih boljši (povprečna stopnja strinjanja $=2,92)$. Jože Bradeško (2003) v raziskavi potrjuje najpomembnejše ugotovitve, trende in razmerja iz študije Evropske centralne banke, pri čemer poudarja korelacijo rasti realnih cen nepremičnin ter realne rasti BDP in prejemkov prebivalstva. To ne pomeni, da spremenjeno gibanje BDP direktno in vnaprej vpliva tudi na gibanje cen nepremičnin, temveč da je gibanje BDP eden od najvplivnejših dejavnikov, ki vplivajo na cene stanovanjskih nepremičnin (Pšunder, 2009). Pozitivno korelacijo med letnim bruto domačim proizvodom na prebivalca in povprečnim številom transakcij nepremičnin potrjuje tudi raziskava dejavnosti trga nepremičnin v Sloveniji v obdobju 2000-2006, ki so jo izvedli Samo Drobne idr. (2009). Iz rezultatov preizkusa je razvidno, da obstaja pozitivna linearna korelacija med analiziranima spremenljivkami s koeficientom povezanosti 0,7 (tveganje 1\%).

Pri pričakovanjih glede spremembe brezposelnosti v naslednjih mesecih so glede na kulturno pripadnost in starost udeležencev opazne statistično pomembne razlike. Japonski udeleženci izražajo večja pričakovanja (povprečna stopnja strinjanja $=2,26$ ) kot slovenski udeleženci (povprečna stopnja strinjanja $=2,12$ ). Kot navaja Alenka Kajzer (2009) se je finančna kriza, ki je izbruhnila v letu 2007, postopoma prenesla v realni sektor in se spremenila v gospodarsko krizo. Za Slovenijo je bila v letu 2007 značilna izjemno visoka gospodarska rast, ki se je v letu 2008 upočasnila, proti konca leta 2008 pa je že bil zabeležen padec gospodarske dejavnosti, merjene z rastjo BDP. Podobna gibanja je bilo mogoče zaznati tudi na Japonskem, kjer se je v letu 2008 končalo nekajletno okrevanje gospodarstva po veliki recesiji, ki jo je ta država doživela v letu 1991. Neugodna gospodarska gibanja v letu 2008 so spremenila gospodarske dejavnosti v obeh državah. To je po mnenju Alenke Kajzer (2009) vplivalo na trg dela, zaznane pa so tudi bistvene spremembe pri gibanju plač v primerjavi z letom 2007. Brezposelnost se je v Sloveniji v zadnjih dveh letih bistveno povečala, kar se verjetno izraža tudi v pričakovanjih naših udeležencev, ki imajo manjša pričakovanja glede spremembe stopnje brezposelnosti v prihodnjih šestih mesecih.

Pri pričakovanjih glede pravega trenutka za nakup nepremičnine v naslednjih šestih mesecih so glede na kulturno pripa- dnost in starost udeležencev opazne statistično pomembne razlike. Po navedbah japonskega urada za spremljanje cen (globalni nepremičninski vodnik, 2009) se zaupanje kupcev $\mathrm{v}$ nepremičninski trg počasi vrača, zato se pričakuje okrevanje stanovanjskega nepremičninskega trga. Tudi kazalnik gospodarskega vzdušja v Sloveniji, ki je pomemben sintezni kazalnik, ki ga sestavljajo indeks zaupanja $\mathrm{v}$ predelovalni dejavnosti in trgovini na drobno ter kazalnik zaupanja potrošnikov, kaže - po strmem padcu v obdobju od druge polovice leta 2007 do začetka leta 2009 - povečanje v letu 2009 in nakazuje rast tudi v letu 2010 (Statistični urad Republike Slovenije, 2010). Slovenski udeleženci imajo večja pričakovanja glede pravega trenutka za nakup nepremičnine (povprečna stopnja strinjanja $=2,78)$. $V$ naši raziskavi se kaže korelacija med pričakovanji udeležencev glede pravega trenutka za nakup nepremičnine in povečanja ponudbe nepremičnin na trgu $(0,244)$ ter negativna korelacija glede pravega trenutka za nakup nepremičnine in gibanja cen nepremičnin $(-0,207)$.

\section{Sklep}

V članku smo raziskovali pričakovanja potencialnih pridobiteljev nepremičnin v različnih kulturnih okoljih, v Sloveniji in na Japonskem. Zanimalo nas je, ali udeleženci glede na pripadnost različnim kulturam izražajo statistično pomembne razlike glede zunanjih pričakovanj. Pod zunanja pričakovanja smo uvrstili pričakovanja udeležencev glede vodenja stanovanjske politike države, davčnih ukrepov države, regulativnih ukrepov države, povečanja ponudbe nepremičnin in gibanja cen na nepremičninskem trgu, spremembe ekonomskega položaja, finančnega položaja potencialnih kupcev, stopnje brezposelnosti v državi in primernosti trenutka za nakup nepremičnine. Sledimo hipotezi, da so statistično pomembne razlike $\mathrm{v}$ zunanjih pričakovanjih potencialnih pridobiteljev nepremičninskih pravic glede na njihovo različno kulturno pripadnost (Slovenija, Japonska).

Kot osrednji pripomoček za merjenje pričakovanj udeležencev smo uporabili vprašalnik, ki smo ga sestavili v sklopu širše raziskave, ki poteka v Sloveniji in na Japonskem in katere temeljni cilj je določiti dejavnike, ki so za potencialne pridobitelje stanovanjskih nepremičninskih pravic odločilni pri odločanju za nakup nepremičnine. $\mathrm{Z}$ vprašalnikom smo pridobili verodostojne podatke, ki smo jih statistično analizirali. Izvedli smo enosmerne analize variance glede različne kulturne pripadnosti udeležencev. $Z$ analizo rezultatov statističnih analiz smo potrdili osnovno hipotezo, da so statistično pomembne razlike v zunanjih pričakovanjih potencialnih pridobiteljev stanovanjskih nepremičninskih pravic glede na njihovo različno kulturno pripadnost.

Iz rezultatov je razvidno, da imajo slovenski udeleženci večja pričakovanja glede povečanja ponudbe nepremičnin na trgu, 
ekonomskega položaja v preteklih mesecih in pravega trenutka za nakup nepremičnine. Japonski udeleženci imajo večja pričakovanja glede stanovanjske politike, davčnih ukrepov, regulativnih ukrepov, pozitivnega gibanja cen nepremičnin v prihodnjih mesecih, ekonomskega položaja v prihodnjih mesecih in brezposelnosti. Majhna pričakovanja slovenskih udeležencev glede lastnega finančnega položaja pa nakazujejo povečanje števila tistih, ki imajo v primerjavi z drugimi manj virov (kot so na primer denar, informacije, zveze in različne veščine) in so zato slabše opremljeni za tržno tekmo. Zanje so izrazito pomembni različni ukrepi, ki jih izvaja država, da pomaga gospodinjstvom pri spopadanju s tveganimi okoliščinami. $\mathrm{Ob}$ upoštevanju, da je glavni vzvod države na trgu nepremičnin prav zakonodaja, pričakovanja udeležencev naše raziskave torej kažejo, da bi bilo treba v Sloveniji na tem področju pridobiti večje zaupanje potrošnikov.

Iz naše raziskave so razvidni trije glavni vzvodi, ki pojasnjujejo nizko izražena zunanja pričakovanja slovenskih udeležencev: prvič, visoko razmerje med stanovanjskimi stroški in razpoložljivim dohodkom v gospodinjstvu, kar pomeni slabo dosegljivost stanovanj; drugič, neurejene evidence nepremičnin in neažurnost zemljiške knjige, kar pomeni še nejasno višino prihajajočega davka na nepremičnine, dalje še vedno nerešena problematika denacionalizacije, otežena prodaja tujcem in otežena posojilna politika države, in tretjič, neustrezni oziroma nezadostni ukrepi glede na poslabšanje stanja na trgu dela in nepremičninskem trgu. Slovenija je zaradi naraščanja brezposelnosti okrepila izvajanje programov zaposlovanja, Japonska pa je sprejela stimulativen ukrep v obliki finančne intervencije. Japonski raziskovalci so ugotovili, da kar $95 \%$ udeležencev meni, da so pri odločanju za nakup stanovanja pomembni dejavniki, kot so ekonomsko stanje, obrestna mera in družinski prihodki, skoraj v celoti po so zanemarili vprašanje o stopnji brezposelnosti. Zato tudi ni presenetljivo, da ukrepi japonske vlade, ki so vključevali zmanjšanje standardne letne obrestne mere, povečanje najvišjega zneska posojil za nove nakupe ali obnovo doma, sočasno pa za najbolj ogroženo skupino podaljšan rok za odplačevanje kreditov s treh na deset let, vodijo v višje izraženo zaupanje potencialnih pridobiteljev nepremičninskih pravic glede zunanjih pričakovanj.

\section{Bojan Grum}

Gea College, Ljubljana, Slovenija

E-pošta: grum.bojan@siol.net

Alenka Temeljotov Salaj

Gea College, Ljubljana, Slovenija

E-pošta: alenka.temeljotov-salaj@gea-college.si

\section{Viri in literatura}

Adair, A., Allen, S., Berry, J., in McGreal, S. (2006): Central and Eastern European propertyinvestment markets: issues of data and transparency. Journal of Property Investments \& Finance, 24(3), str. 211-220. DOI: 10.1108/14635780610659928
Al-Soliman, T. M. (1990): The impact of the surrounding environment on people's perception of major urban environmental attributes. Architecture and Planning, 2, str. 43-60.

Basic act for land. Japan Official Gazette, št., 84/1989. Tokio.

Bastič, M. (2006): Metode raziskovanja. Maribor, Univerza v Mariboru, Ekonomsko-poslovna fakulteta.

Bevc, I. (1997): Premoženjski davek. Gospodarski vestnik, 46(5), str. 89-92.

Bradeško, J. (2003): Trg nepremičnin in Centralna banka. V: Kožar, A. (ur.): Poslovanje z nepremičninami, str. 16-25. Portorož, Gospodarska zbornica Slovenije.

Cirman, A. (2007): Strategija rabe stanovanja mora biti usklajena s strategijo gospodarskega razvoja: stanovanjska raba. Ljubljana, Državni svet Republike Slovenije.

Cohen, D. H., Kozak, R. A., Vidal, N., Spetic, W., in Ide, R. (2005): Performance expectations and needs of the Japanese house consumer. Forest Products Journal, 55(5), str. 37-44.

Drobne, S., Grilj, T., in Lisec, A. (2009): Dejavnost trga nepremičnin v Sloveniji v obdobju 2000-2006. Geodetski vestnik, 53(3), str. 543-560.

Forrest, R., Izuhara, M., in Kennett, P. (2000): Home ownership in Japan's troubled economy, Bristol. Housing Finance, 46, str. 50-55.

Fulgosi, A. (1984): Faktorska analiza. Zagreb, Filozofski fakultet v Zagrebu.

Geodetska uprava Republike Slovenije (2009): Letno poročilo o slovenskem nepremičninskem trgu za leto 2009. Dostopno na: http//:www.gu.gov.si/ (sneto 3. 3. 2010).

Globalni nepremičninski vodnik (2009): House price falls in Japan accelerate. Dostopno na: http://www.globalpropertyguide.com/ Asia/Japan/Price-History (sneto 14. 2. 2010).

Grum, B. (v tisku): Primerjava pričakovanj potencialnih kupcev nepremičnin glede pridobitve nepremičninskih pravic $v$ različnih kulturnih obdobjih: primer Slovenije in Japonske. Doktorska disertacija. Nova Gorica, Evropska pravna fakulteta.

Inštitut za ekonomske in socialne raziskave (2010): Monthly consumer confidence survey covering all of Japan. Dostopno na: http:// www.esri.cao.go.jp/en/stat/shouhi/1001shouhi-e.html (sneto 5. 4. 2010).

Internet 1: http://epp.eurostat.ec.europa.eu/portal/page/portal/ eurostat/home/ (sneto 14. 6. 2010)

Japonski nepremičninski inštitut (2009): Market review. Dostopno na: http://www.reinet.or.jp/en/about.html (sneto 17. 1. 2010).

Japonski statistični urada (2010): Yearly average of monthly disbursements per household. Tokio.

Kajzer, A. (2009): Odziv trga dela na recesijo v Sloveniji. IB Revija, 43(3-4), str. 69-76.

Kobal, D. (2001): Temeljni vidiki samopodobe. Ljubljana, Pedagoški inštitut Ljubljana.

Landholding tax. Japan Official Gazette, št. 69/1991, Tokio.

Macarol, B. (2009): Seznanitev stranke z davčnimi rešitvami pri prometu z nepremičnin. V: Kožar, A. (ur.): Poslovanje z nepremičninami: država, državljani, stanovanja, str. 215-224. Ljubljana, Inštitut za nepremičnine. 
Mandič, S., Hlebec, V., Cirman, A., Andrews, K. D., Filipovič, M., Kos, D., in Sendi, R. (2006): Razvojno raziskovalni projekt stanovanjska anketa. Ljubljana, Univerza v Ljubljani, Fakulteta za družbene vede, Inštitut za družbene vede.

Merton, R. K. (1957): Social theory and social structure. New York, Free Press of Glencoe.

Ministrstvo za okolje, infrastrukturo, transport in turizem (2009): Summary of white paper on land (2009). Tokio.

Public notice of land price law. Japan Official Gazette, št. 49/1969. Tokio.

Pšunder, I. (2009): Demografske spremembe in trg nepremičnin. V: Ramovš, G. (ur): 5. slovenska nepremičninska konferenca, str. 5-12. Ljubljana, Planet GV.

Pušnik, K. (1999): Dileme preobrazbe obdavčenja nepremičnin v Sloveniji. Bilten EDP, 22(2-3), str. 105-126.

Rouwendal, J., in Longhi, S. (2008): the effect of consumer's expectations in a booming housing market: Space-time pattern in the Netherlands, 1999-2000. Housing Studies, 23(3), str. 291-317. DOI: 10.1080/02673030801893107

Sendi, R. (2005): Sodelovanje stanovalcev kot pogoj za uspešno izvedbo prenove stanovanjskih sosesk [Participation by residents as precondition for successful implementation of housing rehabilitation]. Urbani izziv, 16(2), str. 5-15 [133-141]. DOI: 10.5379/urbaniizziv-2005-16-02-001

Statistični urad Republike Slovenije (2009): Slovenija v številkah 2009. Ljubljana.

Šoltes, I. (2009): Problematika javnih naročil na področju poslovanja z nepremičninami: cenitve, upravljanje, gradnja. V: Kožar, A. (ur.): Poslovanje z nepremičninam: država, državljani, stanovanja, str. 14-28. Ljubljana, Inštitut za nepremičnine.

Štritof Brus, M., (2009): Stanovanjska zakonodaja v praksi. Ljubljana, Planet GV.

Temeljotov Salaj, A. (2005): Sinergični učinek opazovalca grajenega okolja [The synergetic effect of the observer on the built environment]. Urbani izziv, 16(2), str. 48-54 [163-167]. DOI: 10.5379/ urbani-izziv-2005-16-02-005

Temeljotov Salaj, A., in Zupančič, D. (2006): Odnos do nepremičnin in organizacijskega okolja. Ljubljana, Slovenski inštitut za revizijo.

Thomas, M. (2008): Generation and housing, carpe diem. The Australian Journal of Business and Informatics, 4, str. 111-119.

Urad za makroekonomske raziskave (2010): Ekonomsko ogledalo (statistična priloga). Ljubljana.

Walonic, D. S. (2007): Survival statistics. Bloomington, MN, StatPac Publications.

Wong, J. T. Y., in Hiu, E. C. M. (2006): Power of expecations. Property Management, 24, str. 496-506. DOI: 10.1108/02637470610710547

Yoshida, Y. (2002): Turning point of land evaluation. Nomura Real Estate, Investment Managemet, str. 1-2.

Zakon o delnem povračilu nadomestila plače. Uradni list Republike Slovenije, št. 42/2009. Ljubljana.

Zakon o delnem subvencioniranju polnega delovnega časa. Uradni list Republike Slovenije, št. 5/2009. Ljubljana.
Zakon o množičnem vrednotenju nepremičnin. Uradni list Republike Slovenije, št. 50/2006. Ljubljana.

Zakona o davkih občanov. Uradni list Socialistične Republike Slovenije, št. 36/1988. Ljubljana. 